\title{
ANALISA PENGARUH CAR, BOPO, NPL, NIM TERHADAP PROFITABILITAS
}

\section{BANK}

\author{
Apriangga Rachmandinur ${ }^{1}$, Purwanto ${ }^{1,2}$ \\ ${ }^{1}$ Fakultas Bisnis, Universitas Presiden, Bekasi, Indonesia \\ ${ }^{2}$ Faculty of Economic and Business, Padjajaran University, Bandung, Indonesia
}

\begin{abstract}
Abstrak
Penelitian ini bertujuan untuk menganalisa pengaruh CAR, BOPO, NPL, dan NIM terhadap profitabilitas bank dengan menggunakan pendekatan kuantitatif. Metode pengumpulan data yang digunakan dalam penelitian ini adalah dokumentasi dan kepustakaan dengan menggunakan tekhnis analisis regresi linear berganda. Subyek dalam penelitian ini adalah 9 bank yaitu OCBCNISP, Maybank, Panin, Mega, Permata, UOB, BJB, BTN, CIMB Niaga tahun 2010-2014. Berdasarkan uji t yang dilakukan diketahui bahwa BOPO, NPL, NIM terbukti berpengaruh secara signifikan terhadap profitabilitas bank. Berdasarkan tabel koefisien determinasi dapat dilihat bahwa nilai Adjusted $R^{2}$ adalah sebesar 0,609. Hal ini dapat diketahui presentase pengaruh variable BOPO, NPL, NIM terhadap variable profitabilitas sebesar $60,9 \%$ sedangkan sisanya sebesar 39,1\% dipengaruhi oleh faktor lain di luar model dalam penelitian ini.
\end{abstract}

Kata kunci : Profitabilitas, CAR, BOPO, NPL, NIM

\section{Abstract}

This research has a purpose to analyze the influence of CAR, BOPO, NPL, and NIM toward the bank profitability with use quantitative method research. Data collection method used in this research is documentation and literature and the analysis technique in this research is multiple regression. The subject on this research is 9 bank that is OCBCNISP, Maybank, Panin, Mega, Permata, UOB, BJB, BTN, CIMB Niaga at 2010-2014. Based on $t$ test used on this research known that BOPO, NPL, and NIM proven has influential in significant on bank profitability. Based on the coefficient of determinant tabel known that It appears that the adjusted is of 0,609 This thing can be known percentage influence of variable BOPO, NPL, NIM toward variable bank profitability is 60,9\% while 39,1\% influence by the others factor Outside a model in this research

Keywords :Profitability, CAR, BOPO, NPL, NIM

\section{Latar Belakang}

Kondisi ekonomi di Indonesia sebelum masa krisis moneter 1997-1998, pertumbuhan ekonomi Indonesia sangatlah pesat, kurs rupiah cenderung relatif stabil. Stabilnya nilai rupiah ini membuat para investor dan pemerintah selaku pihak yang berperan besar dalam pembangunan ekonomi cenderung mengabaikan pinjaman terhadap mata uang asing, khususnya Dollar Amerika Serikat. Dengan tidak adanya perlindungan terhadap rupiah, membawa dampak yang kurang baik pada saat terjadinya resesi ekonomi secara global pada tahun 1997.

Krisis itu diawali dengan merosotnya nilai tukar rupiah terhadap mata uang USD. Hal ini membuat banyak bank di Indonesia mengalami kesulitan keuangan, terutama yang mempunyai pinjaman uang dalam bentuk mata uang asing. Hal ini berakibat pada kebijakan 
pemerintah untuk melikuidasi 16 bank pada masa itu, sehingga mendorong sejumlah nasabah menarik dananya dari bank secara besar-besaran.

Menurut Booklet Perbankan 2014, bank adalah badan usaha yang menghimpun dana dari masyarakat dalam bentuk simpanan dan menyalurkan kembali ke masyarakat dalam bentuk kredit dan atau bentuk lainnya dalam rangka meningkatkan taraf hidup masyarakat. Selain itu bank merupakan salah satu industri yang memegang peran penting dalam perekonomian nasional. Perbankan di Indonesia dituntut untuk memiliki kinerja yang baik untuk menjaga kepercayaan masyarakat dan investor sehingga dapat memicu pertumbuhan ekonomi secara keseluruhan maka dari itu bank berperan sebagai perantara antara pihak yang memiliki dana lebih (surplus unit) dan pihak yang memerlukan dana (deficit unit) dan juga sebagai lembaga yang berfungsi memperlancar aliran lalu lintas pembayaran.

Fungsi dan peran bank sangat penting bagi perekonomian suatu negara karena masyarakat menggunakan jasa bank untuk menyimpan atau meminjam dana guna investasi. Keberadaan bank sangat mempengaruhi ekonomi masyarakat dan merambah sampai ekonomi suatu negara bahkan dalam lingkup internasional, sehingga bank akan selalu berkembang seiring dengan aktivitas ekonomi. Modal utama bank adalah kepercayaan masyarakat yang menyimpan dana di bank yang bersangkutan, kepercayaan masyarakat penting untuk menghindari terjadinya rush and panic dimana masyarakat menarik dananya secara besarbesaran. Peristiwa rush and panic terjadi di Indonesia pada tahun 1998 saat terjadi krisis moneter. Berdasarkan "Global Financial Inclusion Index" yang dirilis oleh World Bank tahun 2013, hanya 20\% dari masyarakat dewasa di Indonesia yang memiliki akses ke dunia perbankan. Dengan pertumbuhan jumlah kantor bank yang tersebar di seluruh daerah di Indonesia tersebut, diharapkan dapat memudahkan akses masyarakat ke dunia perbankan yang pada ujungnya mampu mendorong produktifitas perekonomian dan pertumbuhan ekonomi.

Tabel 1. Jumlah bank dan kantor yang ada di Indonesia

\begin{tabular}{|l|c|c|c|c|c|}
\hline \multicolumn{1}{|c|}{ Indikator } & $\mathbf{2 0 1 0}$ & $\mathbf{2 0 1 1}$ & $\mathbf{2 0 1 2}$ & $\mathbf{2 0 1 3}$ & $\mathbf{2 0 1 4}$ \\
\hline Bank Umum & 122 & 124 & 120 & 120 & 119 \\
\hline Bank Perkreditan Rakyat & 1.706 & 1.669 & 1.653 & 1635 & 1643 \\
\hline Jumlah Bank & $\mathbf{1 . 8 2 8}$ & $\mathbf{1 . 7 9 3}$ & $\mathbf{1 . 7 7 3}$ & $\mathbf{1 . 7 5 5}$ & $\mathbf{1 . 7 6 2}$ \\
\hline Bank Umum & 13.387 & 14.797 & 16.625 & 18.558 & 19.948 \\
\hline Bank Perkreditan Rakyat & 3.910 & 4.172 & 4.425 & 4.678 & 4895 \\
\hline Jumlah kantor & $\mathbf{1 7 . 7 4 7}$ & $\mathbf{1 8 . 9 6 9}$ & $\mathbf{2 1 . 0 5 0}$ & $\mathbf{2 3 . 2 3 6}$ & $\mathbf{2 4 . 8 3 4}$ \\
\hline
\end{tabular}

Sumber : SPI Vol 13 No.9 Agustus 2015 data diolah peneliti, 2016

Jika kita melihat kondisi masyarakat sekarang, sangat jarang orang yang tidak berhubungan dengan bank. Semakin lama bank semakin mendominasi perkembangan ekonomi dan bisnis suatu negara, tidak hanya di negara maju tetapi juga di negara berkembang. Perkembangan dunia perbankan pun mengalami kemajuan yang sangat pesat dan moderen sehingga menyebabkan adanya persaingan antar bank.

Persaingan ini makin dirasakan oleh masyarakat dengan ditawarkannya produkproduk dan jasa-jasa perbankan yang menggiurkan seperti bonus, hadiah, dan penawaranpenawaran lainnya. Selain itu, bank mulai meningkatkan kualitas pelayanannya serta teknologi yang dimiliki masing-masing bank berusaha untuk mendapatkan nasabah sebanyak-banyaknya. Salah satu indikator yang digunakan untuk melihat profitabilitas adalah dengan mencermati laporan kinerja keuangan bank. Bank yang memiliki kinerja keuangan yang bagus menandakan bahwa bank tersebut dapat menghasilkan profitabilitas yang 
maksimal. Profitabilitas merupakan indikator penting dalam laporan kinerja keuangan perusahaan karena memiliki berbagai kegunaan.

Profitabilitas pada umumnya digunakan untuk menilai kondisi suatu perusahaan, pertumbuhan dan kelangsungan hidup perusahaan dalam jangka panjang. Profitabilitas yang tinggi menunjukkan apakah perusahaan tersebut memiliki prospek yang bagus di masa mendatang. Semakin tinggi profitabilitas yang dicapai suatu perusahaan maka semakin terjamin kelangsungan hidup perusahaan. Selain itu tingginya profitabilitas dapat digunakan sebagai bahan pengambilan keputusan bagi investor untuk menanamkan modalnya. Apabila profitabilitas yang dihasilkan tinggi maka investor akan beranggapan bahwa perusahaan tersebut memiliki perkembangan yang bagus sehingga modal yang ditanamkan dapat bertambah dan tingkat pengembalian investasi tinggi.

Ukuran profitabilitas bank yang digunakan pada umumnya adalah Return On Equity (ROE) dan Return On Asset (ROA). ROE hanya menghitung return yang diperoleh dari investasi pemilik perusahaan dalam bisnis tersebut, sedangkan ROA memfokuskan kemampuan perusahaan untuk memperoleh earning dari operasi perusahaan sehingga dapat digunakan sebagai analisis rasio kemampuan perusahaan dalam mengelola asset yang dimilikinya (Siamat, 2008). Pengukuran ROA menurut SE BI No 13/30/DPNP tanggal 16 Desember 2011 adalah dengan cara membandingkan laba sebelum pajak terhadap rata-rata total aset. Semakin tinggi ROA menunjukkan kinerja keuangan yang baik, kerena bank menjalankan kegiatan usahanya dengan lancar sehingga tingkat pengembalian modal tinggi.

Faktor pertama yang diduga berpengaruh terhadap ROA yaitu Capital Adequacy Ratio (CAR). CAR adalah rasio kecukupan modal yang menunjukkan kemampuan bank dalam mempertahankan modal yang mencukupi dan kemampuan manajemen bank dalam mengidentifikasi, mengukur, mengawasi, dan mengontrol resiko-resiko yang timbul yang dapat berpengaruh pada besarnya modal bank (Kuncoro dan Suhardjono, 2011). CAR menunjukkan sejauh mana penurunan aset bank masih dapat ditutupi oleh equity bank yang tersedia (Taswan, 2010). Bank Indonesia menetapkan modal minimal suatu bank adalah 8\%, hal tersebut tercantum dalam SE BI No 15/11/DPNP tanggal 8 April 2013. Semakin tinggi CAR maka semakin banyak modal yang dimiliki oleh bank untuk manutupi penurunan aset.

Faktor kedua yang diduga mempengaruhi ROA adalah Beban Operasional Pendapatan Operasional (BOPO). Pada laporan laba rugi sendiri terdapat dua pos utama, yakni pendapatan operasional dan biaya operasional. Jika pendapatan operasional merupakan hasil yang diperoleh dari kegiatan operasional maka, biaya operasional adalah biaya yang dikeluarkan untuk menjalankan kegiatan operasional tersebut. Jika biaya operasional besar namun hanya menghasilkan pendapatan operasional yang sedikit maka bank tersebut tergolong tidak efisien dalam menjalankan kegiatan operasionalnya. Di lain pihak, biaya operasional yang besar nantinya akan mengurangi jumlah laba bersih yang dapat diperoleh karena biaya operasional merupakan faktor pengurang dalam laporan laba rugi.

Bank yang nilai rasio BOPO-nya tinggi menunjukkan bahwa bank tersebut tidak beroperasi dengan efisien sehingga, memungkinkan suatu bank berada dalam kondisi bermasalah semakin besar. Nilai rasio BOPO yang ideal atau dikategorikan sangat sehat berada antara 50-75\% sesuai dengan ketentuan Bank Indonesia No.6/23/DPNP tanggal 31 Mei 2004. BOPO yang menujukan tingkat efisiensi bank dalam menjalakan operasional seharusnya memiliki dampak terhadap pertumbuhan ROA semakin tinggi BOPO maka semakin tidak efisien bank tersebut. Fee Based Income yang berasal dari kegiatan operasional bank juga termasuk di dalam BOPO.

Faktor ketiga yang diduga mempengaruhi ROA adalah Non Performing Loan (NPL). Dilihat kembali dari fungsi bank untuk menyalurkan dana kepada masyarakat guna menaikan taraf hidup masyarakat memiliki resiko yang cukup tinggi karena, dapat mengakibatkan kredit bermasalah meskipun pengalokasian terbesar dari perbankan adalah dalam bentuk 
kredit yang dapat meningkatkan keuntungan pada bank. Tingkat resiko yang dimiliki bank dalam penyaluran dana kembali kepada masyarakat dapat dilihat dari rasio NPL.

NPL adalah rasio untuk mengetahui kemampuan bank dalam hal menutupi ketidak mampuan dari kewajiban debitur untuk mengembalikan dana yang di berikan dalam bentuk kredit oleh bank. Bank harus berhati-hati dalam pemberian dana kreditnya agar tidak memacu tinggi tingkat NPL karena akan mempengaruhi biaya operasional dari bank yang akan meningkat sehingga berpengaruh buruk pada kinerja dan kesehatan dari bank. Semakin tinggi rasio ini, maka akan semakin buruk kualitas kredit bank yang menyebabkan jumlah kredit bermasalah semakin besar dan menyebabkan kerugian, sebaliknya jika semakin rendah NPL maka laba atau profitabilitas bank tersebut akan semakin meningkat (Puspitasari, 2009). Bank Indonesia dalam PBI No 15/2/PBI/2013 menetapkan bahwa kategori bank sehat NPL tidak melebihi dari $5 \%$.

Faktor keempat yang diduga mempengaruhi ROA adalah Net Interest Margin (NIM). SE BI No 13/13/DPNP tanggal 16 Desember 2011, menyatakan bahwa NIM merupakan perbandingan persentase pendapatan bunga dan rata-rata aset produktif. Rasio ini digunakan untuk menghitung kemampuan bank dalam menghasilkan pendapatan bunga bersih dengan penempatan aset yang tersedia. Semakin besar hasil bunga yang didapatkan bank atas pengelolaan asetnya maka hal tersebut dapat meminimalisir terjadinya masalah. NIM bertujuan untuk mengevaluasi kinerja bank dalam mengelola berbagai resiko yang mungkin terjadi pada suku bunga. Semakin tinggi NIM yang diperoleh bank maka semakin tinggi pula ROA bank karena pendapatan bunga atas aktiva produktif yang dikelola bank semakin bertambah. Apabila selisih antara pendapatan bunga dengan biaya bunga yang didapat besar, maka profitabilitas yang didapat pun akan semakin besar (Taswan, 2010).

Bank yang diteliti adalah 9 bank BUKU III yaitu singkatan dari Bank Umum Kelompok Usaha III (PBI Nomor 14/26/PBI/2012) bank di BUKU III tersebut diantaranya OCBCNISP, Maybank, Panin, Mega, Permata, UOB, BJB, BTN, CIMB Niaga yang namanya sudah tercatat dalam Bursa Efek Indonesia dengan rentan waktu 5 tahun dari tahun 2010 sampai dengan 2014. Selama periode tersebut terdapat fluktuasi terhadap rasio-rasio keuangan perbankan. Berikut adalah perkembangan rasio-rasio keungan perbankan diantaranya ROA, CAR, BOPO, NPL, NIM pada bank OCBCNISP, Maybank, Panin, Mega, Permata, UOB, BJB, BTN, CIMB Niaga dan rentan waktu periode 2010-2014 dengan sumber yang didapat dari laporan tahunan bank yang sudah dipublikasi.

Sebagai pembuktian bahwa adanya pengaruh yang signifikan dari masing-masing rasio keuangan serta dapat memberi bukti empirik. Pada kesempatan ini peneliti mengambil contoh 9 bank umum devisa yang berada pada kategori Bank BUKU III dengan modal ratarata di bawah 30 Trilliun dan namanya tercatat dalam Bursa

Efek Indonesia yaitu OCBCNISP, Maybank, Panin, Mega, Permata, UOB, BJB, BTN, dan CIMB Niaga. Berdasarkan latar belakang yang telah diuraikan maka identifikasi masalah dari penelitian ini adalah sebagai berikut :

1. Profitabilitas merupakan dasar kunci dari tingkat kesehatan sebuah bank. Untuk mengukur profitabilitas sebuah bank pada umumnya biasa menggunakan ROA dimana hasil dari besar ROA akan menunjukan seberapa besar keuntungan pada bank dalam suatu periode.

2. Modal inti bank menunjukan tingkat kesehatan bank yang memicu tingkat kepercayaan dari masyarakat untuk menghimpun dana pada bank dan investor yang menanamkan modal pada bank.

3. Tingkat efisiensi bank dalam menjalankan kegiatan operasional merupakan hal yang memiliki pengaruh pada peningkatan profitabilitas bank.

4. Kemampuan bank dalam mengelola kredit bermasalah dalam era persaingan bisnis perbankan yang semakin ketat dalam upaya peningkatan profitabilitas bank. 
5. Kemampuan manajemen bank dalam mengelola aktiva produktifnya dalam rangka menghasilkan pendapatan bunga bersih menujukan tingkat profitabiltas bank.

6. Untuk mengetahui tingkat profitabilitas dari bank dapat diukur dari ROA yang dipengaruhi oleh tinggi rendah rasio CAR, BOPO, NPL, NIM.

\section{Landasan Teori}

\section{Profitabilitas ( Return on Asset / ROA)}

Profitabilitas bank adalah hal yang sangat penting karena pendapatan bank ini merupakan sasaran utama yang harus dicapai sebab, bank didirikan untuk mencapai tujuan profit atau laba dimana laba merupakan kunci utama dalam kontinuitas atau perkembangan bank. Kemampuan bank dalam memperoleh laba tercermin dalam laporan keuangan bank. Profitabilitas perusahaan merupakan unsur yang mempengaruhi kebijakan investor atas investasinya. Kemampuan perusahaan dalam menghasilkan laba dapat menarik para investor untuk menanamkan dananya guna menambah modal. Apabila profitabilitas suatu perusahaan rendah maka investor akan menarik dananya. Bagi perusahaan profitabilitas digunakan sebagai bahan evaluasi atas usaha yang didirikan.

Ukuran profitabilitas pada industri perbankan biasa digunakan umumnya dengan Return on Asset (ROA) dan Return on Equity (ROE). ROA memfokuskan kemampuan perusahaan untuk memperoleh profitabilitas dalam kegiatan operasinya sedangkan ROE hanya mengukur return yang diperoleh dari investasi pemilik perusahaan dalam bisnis tersebut (Siamat, 2008). Pada penelitian ini rasio profitabilitas yang digunakan adalah ROA. Alasan penggunaan ROA sebagai salah satu rasio yang mengukur profitabilitas bank dikarenakan Bank Indonesia sebagai pembina dan pengawas perbankan lebih mementingkan aset yang dananya berasal dari masyarakat (Buyung, 2009).

ROA adalah rasio yang menunjukan hasil (return) atas jumlah aktiva yang digunakan dalam perusahaan. Selain itu, ROA memberikan ukuran yang lebih baik atas profitabilitas perusahaan karena menunjukan efektivitas manajemen dalam menggunakan aktiva untuk memperoleh pendapatan (Kasmir, 2012). Retutrn on Asset adalah sama dengan Return on Investment dalam analisa keuangan mempunyai arti yang sangat penting sebagai salah satu teknik analisa keuangan yang bersifat menyeluruh (komprehensif). Return on Asset juga sering disebut sebagai rentabilitas ekonomis yang merupakan ukuran kemampuan perusahaan dalam menghasilkan laba dengan semua aktiva yang dimiliki perusahaan (Sutrisno, 2009). Analisis ini sudah merupakan teknik analisa yang lazim di gunakan oleh pimpinan perusahaan untuk mengukur efektivitas dari keseluruhan operasi perusahaan (Munawir, 2010).

ROA menggambarkan perputaran aktiva diukur dari penjualan. Semakin besar rasio ini maka semakin baik dan dalam hal ini berarti bahwa aktiva dapat lebih cepat berputar dan meraih laba (Harahap, 2010). Return on asset sering juga disebut sebagai Return on Investment, karena ROA ini melihat sejauh mana investasi yang telah ditanamkan mampu memberikan pengembalian keuntungan sesuai dengan yang diharapkan dan investasi tersebut sebenarnya sama dengan aset perusahaan yang ditanamkan atau ditempatkan (Fahmi, 2012). Rasio ini menunjukkan berapa besar laba bersih diperoleh perusahaan bila diukur dari nilai asetnya. Menurut Bank Indonesia, ROA merupakan perbandingan antara laba sebelum pajak dengan rata-rata total aset dalam suatu periode.

Salah satu faktor dipilihnya rasio ini mengingat keuntungan yang diperoleh dari penggunaan aset dapat mencerminkan tingkat efisiensi usaha suatu bank. Semakin besar ROA suatu bank semakin besar pula keuntungan yang dicapai bank tersebut serta semakin baik posisi penggunaan aset di dalam bank. 
ROA dapat dirumuskan sebagai berikut :

$$
R O A=\frac{\text { Laba Bersih }}{\text { Total Aktiva }} \times 100 \%
$$

Sumber : SE BI No 13/30/DPNP Tanggal 16 Desember 2011

\section{Capital Adequacy Ratio (CAR)}

Capital Adequacy Ratio (CAR) adalah rasio permodalan yang menunjukkan kemampuan bank dalam mengembangkan usaha dan menampung resiko kerugian yang diakibatkan oleh kegiatan operasional perusahaan. Semakin banyak modal yang dihimpun bank maka operasional bank dapat berjalan lancar. CAR juga dapat digunakan sebagai rasio permodalan yang digunakan untuk melindungi nasabah sehingga mempertahankan kepercayaan terhadap bank. Setiap bank diwajibkan untuk memelihara rasio kecukupan modal atau CAR. Fungsi modal bagi bank adalah (Taswan, 2010) :

a. Melindungi deposan dengan menangkal semua kerugian usaha

perbankan sebagai akibat salah satu resiko usaha.

b. Untuk meningkatkan kepercayaan masyarakat dengan kemampuan bank untuk memenuhi kewajiban yang telah jatuh tempo.

c. Membiayai kebutuhan aktiva tetap.

d. Mengusahakan kekurangan modal tersebut dari luar.

Dengan kata lain, semakin kecil resiko suatu bank dengan modal yang besar maka semakin besar keuntungan yang diperoleh bank. Seperti diketahui bahwa CAR juga biasa disebut dengan rasio kecukupan modal, yang berarti jumlah modal sendiri yang diperlukan untuk menutup resiko kerugian yang mungkin timbul dari penanaman aktiva-aktiva yang mengandung resiko serta membiayai seluruh benda tetap dan inventaris.

Rasio kecukupan modal merupakan faktor yang penting bagi bank dalam rangka mengembangkan usaha dan menampung kerugian serta mencerminkan kesehatan bank yang bertujuan untuk menjaga kepercayaan masyarakat kepada perbankan, melindungi dana masyarakat pada bank bersangkutan. Faktor permodalan sangat penting dalam menjalankan kegiatan operasional bank dan menunjang kebutuhannya, dengan kualitas pihak manajemen dalam pengelolaan kegiatan perbankan akan mendapatkan tingkat laba yang diharapkan. Dengan pengelolaan yang baik suatu bank akan terus meningkatkan modal dengan memperhatikan indikator kesehatan permodalan yaitu CAR.

CAR adalah rasio yang memperlihatkan seberapa besar jumlah seluruh aktiva bank yang mengandung unsur resiko (kredit, penyertaan, surat berharga, tagihan pada bank lain) yang ikut dibiayai dari modal sendiri bank, disamping memperoleh dana-dana dari sumber-sumber diluar bank. Semakin bersar CAR maka keuntungan bank juga akan semakin besar (Dendawijaya, 2009). CAR adalah kecukupan modal yang menunjukan kemampuan bank dalam mempertahankan modal yang mencukupi dan kemampuan manajemen bank dalam mengidentifikasi, mengukur, mengawasi, dan mengontrol resiko-resiko yang timbul yang dapat berpengaruh terhadap besarnya modal bank (Kuncoro dan Suhardjono, 2011).

Dengan kata lain, semakin kecil resiko suatu bank maka semakin besar keuntungan yang diperoleh bank (Kuncoro dan Suhardjono, 2011). Dengan ini maka, CAR adalah rasio kinerja bank untuk mengukur kecukupan modal yang dimiliki bank untuk menunjang aktiva yang mengandung atau menghasilkan resiko, misalkan kredit yang diberikan. CAR 
merupakan indikator terhadap kemampuan bank untuk menutupi penurunan aktivanya sebagai akibat dari kerugian bank yang disebabkan oleh aktiva yang beresiko.

Secara sistematis CAR dapat dirumuskan sebagai berikut :

$$
C A R=\frac{\text { Modal }}{A T M R} \times 100 \%
$$

\section{Sumber : SE BI No 13/30/DPNP Tanggal 16 Desember 2011.}

Modal terdiri dari modal inti dan modal pelengkap. Modal inti terdiri dari modal disetor dan cadangan tambahan modal yang terdiri dari faktor penambah (agio, modal sumbangan, cadangan umum modal, cadangan tujuan modal dll). Sedangkan modal pelengkap terdiri dari cadangan revaluasi aktiva tetap, modal pinjaman, pinjaman subordinasi dan peningkatan nilai penyertaan pada portofolio. ATMR (Aktiva Tertimbang Menurut Resiko) terdiri dari aktiva neraca yang diberikan bobot sesuai kadar resiko kredit yang melekat. ATMR diperoleh dengan cara mengalikan nilai nominal aktiva dengan bobot resiko.

\section{Beban Operasional terhadap Pendapatan Operasional (BOPO)}

Pada penelitian ini variabel BOPO diambil sebagai salah satu variabel atau faktor yang mempengaruhi kinerja keuangan bank, karena bagaimanapun juga jika kita berbicara mengenai kinerja suatu perusahaan pastilah juga berhubungan dengan efisiensi operasi perusahaan tersebut. Rasio yang sering disebut rasio efisiensi ini digunakan untuk mengukur kemampuan manajemen bank dalam mengendalikan biaya operasional terhadap pendapatan operasional. Semakin kecil rasio ini berarti semakin efisien biaya operasional yang dikeluarkan bank yang bersangkutan sehingga kemungkinan suatu bank dalam kondisi bermasalah semakin kecil.

Semakin besar BOPO maka akan semakin kecil atau menurun kinerja keuangan perbankan. Begitu juga sebaliknya, jika BOPO semakin kecil, maka dapat disimpulkan bahwa kinerja keuangan perbankan semakin meningkat atau membaik (Ambo, 2013). Beban Operasional terhadap Pendapatan Operasional rasio ini mengindikasikan efisiensi operasional suatu bank. Semakin tinggi rasio ini menunjukkan semakin tidak efisien operasional bank (Taswan, 2010), BOPO merupakan rasio antara biaya operasional terhadap pendapatan operasional (Dendawijaya, 2009). Mengingat kegiatan utama bank adalah sebagai perantara pihak yang kelebihan dana kepada pihak yang kekurangan dana, maka beban dan pendapatan operasional bank didominasi oleh biaya bunga dan hasil bunga. Biaya operasi merupakan biaya yang dikeluarkan oleh bank dalam rangka menjalankan aktivitas usaha utamanya seperti biaya bunga, biaya pemasaran, biaya tenaga kerja dan biaya operasional lainnya.

Pendapatan operasional merupakan pendapatan utama bank yaitu pendapatan yang diperoleh dari penempatan dana dalam bentuk kredit dan pendapatan operasi lainnya seperti biaya mutasi rekening, biaya surat referensi bank dan surat konfirmasi bank. Semakin kecil BOPO menunjukkan semakin efisien bank dalam menjalankan aktivitas usahanya. Bank yang sehat rasio BOPO-nya kurang dari satu sebaliknya bank yang kurang sehat, rasio BOPO-nya lebih dari satu. Menurut ketentuan Bank Indonesia efisiensi operasi diukur dengan BOPO. Bank yang sehat ketentuan dari BI harus memiliki BOPO $<93,52 \%$. Rasio Beban Operasional Pendapatan Operasional (BOPO) sering disebut rasio efisiensi digunakan untuk mengukur kemampuan manajemen bank dalam mengendalikan biaya operasional terhadap pendapatan operasional. Semakin kecil rasio ini berarti semakin efisien biaya operasional yang dikeluarkan bank tersebut. 
Secara sistematis BOPO dapat dirumuskan sebagai berikut:

$$
\text { BOPO }=\frac{\text { Biaya Oprasional }}{\text { Pendapatan Oprasional }} \times 100 \%
$$

Sumber : SE BI No 13/30/DPNP Tanggal 16 Desember 2011.

\section{Non Performing Loan (NPL)}

Menurut Peraturan Bank Indonesia nomor 5 Tahun 2003 resiko adalah potensi terjadinya peristiwa (event) yang menimbulkan kerugian. Seperti diketahui bahwa perbankan di Indonesia mengalami perkembangan pesat. Non Performing Loan (NPL) adalah rasio kredit bermasalah yang menurut Peraturan BI No 15/2/PBI/2013, NPL tidak lebih dari $5 \%$ total kredit dan penyelesaiannya bersifat kompleks. Kredit bermasalah yang tinggi dapat menimbulkan keengganan bank untuk menyalurkan kredit karena harus membentuk cadangan penghapusan yang besar (Siamat, 2005). Seiring dengan perkembangan pesat tersebut juga diiringi dengan resiko tinggi yang harus dihadapi oleh bank. Salah satu resiko yang dapat mempengaruhi profitabilitas atau tingkat keuntungan yang diraih oleh bank yaitu resiko kredit.

Resiko kredit didefinisikan sebagai resiko kerugian yang dikaitkan dengan kemungkinan kegagalan klien membayar kewajibannya atau resiko dimana debitur tidak dapat melunasi hutangnya (Ghozali, 2011). Rasio keuangan yang digunakan sebagai proxy dari resiko kredit adalah rasio NPL. Rasio ini menunjukkan kemampuan bank dalam mengelola kredit bermasalah yang diberikan oleh bank. Salah satu resiko yang muncul akibat semakin kompleksnya kegiatan perbankan adalah munculnya NPL yang semakin besar. Semakin kecil NPL semakin kecil pula resiko kredit yang ditanggung bank. Bank dengan NPL yang tinggi akan memperbesar biaya baik pencadangan aktiva produktif maupun biaya lainnya, sehingga berpotensi terhadap kerugian bank (Mawardi, 2005).

Kredit bermasalah adalah pinjaman yang mengalami kesulitan akibat faktor kesengajaan dan atau karena faktor eksternal diluar kemampuan kendali debitur (Siamat, 2005). Tingginya NPL akan meningkatkan premi resiko yang berdampak pada tingginya suku bunga kredit yang terlampau tinggi akan mempengaruhi permintaan masyarakat akan kredit (Arma, 2010). Peningkatan Non Performing Loan dalam jumlah yang banyak dapat menimbulkan masalah bagi kesehatan bank, oleh karena itu bank dituntut untuk selalu menjaga kredit tidak dalam posisi NPL yang tinggi. Sebuah bank yang dirongrong oleh kredit bermasalah dalam jumlah besar akan cenderung menurunkan profitabilitasnya (Sutojo, 2008). kredit bermasalah secara umum adalah semua kredit yang mengandung resiko tinggi atau kredit bermasalah adalah kredit-kredit yang mengandung kelemahan atau tidak memenuhi standar kualitas yang telah ditetapkan oleh bank (Arthesa, 2006).

Dalam dunia perbankan internasional, kredit dapat dikategorikan ke dalam kredit bermasalah jika terjadinya keterlambatan pembayaran bunga dan atau kredit induk lebih dari 90 hari sejak tanggal jatuh temponya, tidak dilunasi sama sekali, atau diperlukan negosiasi kembali atas syarat pembayaran kembali kredit dan bunga yang tercantum dalam perjanjian kredit (Sutojo, 2008). Agar dapat menentukan tingkat wajar atau sehat maka ditentukan ukuran standar yang tepat untuk NPL. Terdapat beberapa hal yang menyebabkan naik turunnya NPL suatu bank, diantaranya kemauan atau itikad baik debitur dan kebijakan pemerintah dan Bank Indonesia terakhir adalah kondisi perekonomian. Bank Indonesia melalui Peraturan Bank Indonesia (PBI) menetapkan rasio NPL adalah sebesar 5\%. 
Semakin tinggi nilai NPL maka bank tersebut tidak sehat. NPL yang tinggi menyebabkan menurunnya laba yang akan diterima oleh bank. Menurut perhitungan rasio keuangan Bank Indonesia, NPL didapat dari perbandingan antara kredit bermasalah dengan total kredit. Kredit bermasalah meliputi kredit kurang lancar, diragukan, dan macet.

Secara sistematis NPL dapat dirumuskan sebagai berikut: (SE BI No13/30/DPNP Tanggal 16 Desember 2011).

$$
N P L=\frac{\text { Kredit Bermasalah }}{\text { Total Kredit }} \times 100 \%
$$

\section{Sumber : SE BI No 13/30/DPNP Tanggal 16 Desember 2011.}

\section{Net Interest Margin (NIM)}

Net Interest Margin (NIM) merupakan rasio pendapatan bunga bersih yang didapat oleh bank. Pendapatan tersebut diperoleh bank dari bunga yang diterima dari pinjaman atau jasa-jasa yang diberikan bank kepada nasabah kemudian dikurangi oleh beban bunga dari sumber dana yang telah dikumpulkan. Menurut SE BI No 6/23/DPNP tanggal 31 Mei 2004, Net Interest Margin adalah perbandingan antara pendapatan bunga bersih dengan rata-rata aktiva produktifnya. Rasio NIM merupakan rasio yang digunakan untuk mengukur kemampuan manajemen bank dalam mengelola aktiva produktifnya untuk menghasilkan pendapatan bunga bersih (Pandia, 2012).

Rasio NIM juga digunakan untuk mengukur kemampuan manajemen bank dalam menghasilkan pendapatan dari bunga dengan melihat kinerja bank dalam menyalurkan kredit, mengingat pendapatan operasional bank sangat tergantung dari selisih bunga dari kredit yang disalurkan (Mahardian, 2008). NIM merupakan selisih bunga simpanan DPK (Dana Pihak Ketiga) dengan bunga pinjaman (Ghani dan Sugiyanto, 2008). NIM merupakan perbandingan antara presentase hasil bunga terhadap total asset atau terhadap total earning asset (Riyadi, 2006).

Semakin besar NIM suatu bank, mengindikasikan semakin baik kinerja dalam pemberian jasa-jasa perbankan. Untuk dapat meningkatkan NIM suatu bank perlu dilakukan penekanan terhadap beban bunga. Dalam hal ini beban bunga adalah bunga yang dibayarkan bank kepada masing-masing sumber dana yang bersangkutan. Tingkat suku bunga yang diberikan oleh bank menentukan besarnya NIM. Menurut Surat Edaran No.6/23/DPNP tanggal 31 Mei 2004 Bank Indonesia menetapkan kriteria rasio NIM adalah $6 \%$. Semakin besar rasio ini maka meningkatnya pendapatan bunga atas aktiva produktif yang dikelola bank sehingga kemungkinan suatu bank dalam kondisi bermasalah semakin kecil.

Secara sistematis NIM dapat dirumuskan sebagai berikut:

$$
N I M=\frac{\text { Pendapatan bunga bersih }}{\text { Rata }- \text { rata aktiva produktif }} \times 100 \%
$$

Sumber : SE BI No 13/30/DPNP Tanggal 16 Desember 2011.

\section{Metode Penelitian dan Hipotesis}

Pendekatan yang digunakan dalam penelitian adalah pendekatan kuantitatif, yaitu menganalisis pengukuran fenomena ekonomi yang merupakan gabungan antara teori ekonomi (informasi laporan keuangan), model matematika dan statistika yang diklasifikasikan dalam kategori tertentu dengan menggunakan tabel-tabel tertentu guna 
mempermudah dalam menganalisis dengan menggunakan program IBM SPSS versi 22. Sedangkan teknik analisis yang digunakan adalah teknik analisis regresi linier berganda, untuk melihat hubungan antara satu variabel terikat dengan lebih satu variabel bebas.

\section{Instrumen Penelitian}

Instrumen penelitian adalah alat atau fasilitas yang digunakan oleh peneliti dalam mengumpulkan data untuk mempermudah pekerjaan dan hasil yang didapatkan lebih cermat, lebih lengkap dan sistematis sehingga lebih mudah diolah (Arikunto, 2010). Instrumen penelitian digunakan untuk melakukan pengukuran dengan tujuan menghasilkan data yang akurat.

Instrumen yang digunakan adalah :

\section{Studi literatur}

Studi literatur diperlukan untuk mencari data sekunder yang diperlukan dalam penelitian dan juga untuk mengetahui sampai dimana ilmu yang berhubungan dengan penelitian sudah berkembang (Nazir, 2013). Sumber studi literatur yang digunakan berasal dari beberapa sumber, diantaranya adalah (Nazir, 2013) :

a. Buku teks

Buku teks adalah tulisan ilmiah yang digunakan sebagai buku wajib dalam mata kuliah tertentu.

b. Jurnal

Jurnal adalah majalah ilmiah yang berisi hasil seminar atau tulisan ilmiah yang diterbitkan oleh himpunan profesi ilmiah. Abstract jurnal adalah majalah ilmiah yang berisi singkatan atau ikhtisar (judul, metode serta kesimpulan) dari artikel pada jurnal terbaru.

c. Periodical

Periodical adalah majalah ilmiah yang diterbitkan secara berkala yang berisi hasil penelitian yang dikerjakan.

d. Yearbook

Yearbook adalah buku yang berisi fakta dan statistik selama satu tahun dan diterbitkan tiap tahun oleh lembaga pemerintah atau swasta. Yearbook yang dikeluarkan dapat juga membahas suatu masalah bidang ilmu.

e. Buletin

Buletin adalah tulisan ilmiah pendek yang berisi tentang catatan ilmiah mengenai suatu kegiatan operasional dan diterbitkan secara berkala.

f. Annual Review

Annual review berisi ulasan tentang literatur yang telah diterbitkan selama setahun atau beberapa tahun sebelumnya.

Penelitian ini menggunakan dua instrumen pengumpulan data, yaitu:

\section{Studi Pustaka}

Penelitian ini menggunakan data dan teori yang relevan terhadap permasalahan yang akan diteliti dengan melakukan studi pustaka terhadap literatur dan bahan pustaka lainnya seperti artikel, jurnal, buku dan penelitian terdahulu. Studi kepustakaan berkaitan dengan kajian teoritis dan referensi lain yang berkaitan dengan nilai, budaya dan norma yang berkembang pada situasi sosial yang diteliti, selain itu studi kepustakaan sangat penting 
dalam melakukan penelitian, hal ini dikarenakan penelitian tidak akan lepas dari literaturliteratur ilmiah ( Sugiyono, 2012)

\section{Studi Dokumentasi}

Studi dokumentasi merupakan suatu teknik pengumpulan data dengan cara mempelajari dokumen untuk mendapatkan data atau informasi yang memiliki hubungan dengan masalah yang sedang diteliti. Studi dokumentasi adalah catatan peristiwa yang sudah berlalu. Dokumentasi dapat berupa tulisan, gambar, dan karya monumental dari seseorang (Sugiyono, 2012). Studi dokumentasi dalam penelitian ini adalah dengan mengumpulkan data yang berupa laporan tahunan yang diperoleh dari laporan keuangan yang sudah dipublikasi oleh perusahaan dan Bank Indonesia. Hal ini dilakukan agar informasi dan data yang diperoleh benar bersumber dari objek yang akan dijadikan penelitian.

\section{Desain sampel}

a. Populasi

Populasi adalah suatu kumpulan individu yang mempunyai kualitas dan ciri-ciri yang telah ditetapkan (Nazir, 2013). Keterangan mengenai suatu populasi dapat dikumpulkan dengan dua cara, yaitu :

1) Sensus atau complete enumeration

Sensus adalah menghitung setiap unit populasi

2) Sampel atau sample enumeration

Perhitungan yang hanya dilakukan pada bagian unit populasi saja. Keterangan tentang sesuatu hal diambil dari wakil populasi atau sampel.

Populasi merupakan keseluruhan objek peneletian dan populasi dalam penelitian ini merupakan populasi terbatas, karena sumber data yang diperoleh secara kuantitatif dan jumlahnya dapat dihitung. Populasi dalam penelitian ini adalah bank kategori BUKU (Bank Umum Kelompok Usaha) III yang tercatat namanya di Bursa Efek Indonesia.

\section{b. Sampel}

Sampel adalah objek penelitian yang diambil dari suatu populasi dan memiliki karakteristik yang sama dengan populasi tersebut. Sampel adalah bagian dari populasi yang memiliki karakteristik yang sama dengan populasi (Sugiyono, 2012). Sampel yang digunakan dalam penelitian adalah 9 bank BUKU (Bank Umum Kelompok Usaha) III yang namanya tercatat dalam Bursa Efek Indonesia yaitu, OCBCNISP, Maybank, Panin, Mega, Permata, UOB, BJB, BTN, dan CIMB Niaga. Penelitian ini menggunakan data pengamatan selama lima tahun yaitu tahun 2010-2014.

\section{Uji Asumsi Klasik}

Model regresi yang digunakan dalam menguji hipotesis haruslah menghindari kemungkinan terjadinya penyimpangan asumsi klasik. Asumsi klasik regresi menurut Ghozali (2011) terdiri dari uji normalitas, uji heteroskedastisitas, uji multikolineritas, dan uji autokorelasi.

\section{Regresi Linier Berganda}

Dalam analisis regresi, selain mengukur kekuatan hubungan antara dua variabel atau lebih, juga menunjukkan arah hubungan antara variabel dependen dengan variabel 
independen (Ghozali, 2011). Model regresi linear berganda (multiple linier regresion method), digunakan untuk mengetahui apakah terdapat pengaruh yang signifikan dari satu variabel terikat (dependen) dan lebih dari satu variabel bebas (independen). Penelitian ini menggunakan data sekunder yang diperoleh dari laporan keuangan 9 Bank BUKU (Bank Umum Kelompok Usaha) III OCBCNISP, Maybank, Panin, Mega, Permata, UOB, BJB, BTN, dan CIMB Niaga periode 2010 - 2014 yang dipublikasikan dan dikutip dari laporan tahunan serta tercantum dalam Direktori Perbankan Indonesia yang diterbitkan oleh Bank Indonesia. Data penelitian adalah gabungan antara deret waktu (time series) dan cross section selama kurun waktu 2010 sampai dengan tahun 2014. Jangka waktu tersebut dipandang cukup untuk mengikuti perkembangan kinerja bank. Dalam penelitian ini yang menjadi variabel terikat adalah profitabilitas (ROA), sedangkan yang menjadi variabel bebas CAR, BOPO, NPL dan NIM. Model hubungan ROA dengan CAR, BOPO, NPL, dan NIM dapat disusun dalam persamaan linear sebagai berikut :

$Y=\alpha+\beta_{1} X_{1}+\beta_{2} X_{3}+B_{2} X_{2}+B_{1} X_{1}+e$

\section{Sumber : Ghozali, 2011 diolah peneiliti}

$\mathrm{Y}=$ Return On Asset (ROA)

$\mathrm{a}=$ konstanta

$\beta_{1}-\beta_{4}=$ koefisien regresi, merupakan besarnya perubahan variabel terikat akibat perubahan tiap-tiap unit variabel bebas.

$\mathrm{X}_{1}=$ Capital Adequacy Ratio (CAR)

$\mathrm{X}_{2}=$ Beban Oprasional Pendapatan Oprasional (BOPO)

$\mathrm{X}_{3}=$ Non Performing Loan (NPL)

$\mathrm{X}_{4}=$ Net Interest Margin (NIM)

$\mathrm{e}=$ Kesalahan residual (error)

\section{Hipotesis}

Adapun hipotesis yang akan diuji kebenarannya adalah sebagai berikut :

a. Hipostesis 1: CAR memiliki pengaruh signifikan terhadap ROA.

b. Hipostesis 2: BOPO memiliki pengaruh signifikan terhadap ROA.

c. Hipostesis 3: NPL memiliki pengaruh signifikan terhadap ROA.

d. Hipostesis 4 : NIM memiliki pengaruh signifikan terhadap ROA.

e. Hipostesis 5 : Secara simultan CAR, BOPO, NPL, NIM berpengaruh signifikan terhadap ROA

\section{Hasil Penelitian dan Diskusi}

\section{Analisa Deskriptif}

Pada bagian ini akan dideskripsikan data dari masing-masing variabel yang diolah mengunakan SPSS versi 22. Adapun hasil olahan data dari SPSS dalam bentuk deskriftif statistik akan menampilkan karakteristik dari sampel yang digunakan antara lain yaitu; jumlah sampel (n), mean, minimum, maksimum serta, standar deviasi dari masing-masing variabel sebagai berikut : 
Tabel 2. Statistik deskriptif ROA, CAR, BOPO, NPL, NIM

Descriptive Statistics

\begin{tabular}{|l|r|r|r|r|r|}
\hline & $\mathrm{N}$ & Minimum & Maximum & Mean & $\begin{array}{c}\text { Std. } \\
\text { Deviation }\end{array}$ \\
\hline ROA & 45 & $0,67 \%$ & $3,31 \%$ & $1,97 \%$ & $0,62 \%$ \\
CAR & 45 & $11,70 \%$ & $22,85 \%$ & $15,87 \%$ & $2,39 \%$ \\
BOPO & 45 & $44,76 \%$ & $93,03 \%$ & $78,79 \%$ & $11,38 \%$ \\
NPL & 45 & $0,73 \%$ & $4,36 \%$ & $2,29 \%$ & $0,97 \%$ \\
NIM & 45 & $3,63 \%$ & $7,96 \%$ & $5,28 \%$ & $0,95 \%$ \\
Valid N & & & & & \\
(listwise) & 45 & & & & \\
& & & & & \\
\hline
\end{tabular}

Sumber : Data Sekunder diolah menggukana SPSS versi 22, 2016

Bedasarkan tabel 2 dapat dilihat statistik deskriptif dari masing-masing variabel. Dari 45 data sampel ini variabel CAR memiliki nilai minimum sebesar $11,70 \%$, maksimum sebesar 22,85\% dan standar deviasi 2,39\% yang jauh lebih kecil dari mean yang sebesar $15,87 \%$ membuktikan bahwa variabel CAR terdistribusi secara baik. Lalu pada variabel BOPO dapat dilihat nilai minimum sebesar 44,76\%, maksimum $93,03 \%$, dan standar deviasi sebesar $11,38 \%$ lebih kecil dari nilai mean yang sebesar $78,79 \%$ dikatakan juga baik terdistribusi. Pada variabel NPL nilai minimum sebesar $0,73 \%$, maksimum $4,36 \%$, dan standar deviasi $0,97 \%$ lebih kecil dari nilai mean yang sebesar 2,29\% menunjukan NPL juga terdistribusi secara baik hal ini di dukung oleh kebijakan Bank Indonesia yang membatasi rasio NPL adalah 5\% jika lebih dari itu maka dapat dikatakan bank tidak sehat. Untuk pendapatan dari bunga bersih yaitu variabel NIM juga dapat dilihat nilai minimum sebesar 3,63\%, maksimum 7,96\%, dan standar deviasi sebesar 0,95\% lebih kecil dari nilai rata-rata mean 5,28\% menujukan pendapatan dari bunga bersih juga terdistribusi secara baik. Variabel ROA memilki nilai minimum $0,67 \%$, nilai maksimum 3,31\%, dan standar deviasi sebesar $0,62 \%$ berada di bawah nilai mean sebesar $1,97 \%$ membuktikan juga bahwa tidak ada penyimpangan yang terlalu jauh atau terdistribusi secara baik. Nilai standar deviasi yang lebih besar dari mean akan menunjukan adanya penyimpangan (Outlier) yang biasanya muncul karna data yang terlalu ekstrim (Ghozali, 2009).

\section{Hasil Pengujian Regresi Berganda}

Tabel 3. Pengujian Regresi Berganda Coefficients $^{\mathrm{a}}$

\begin{tabular}{|rl|r|r|r|}
\hline \multirow{2}{*}{ Model } & \multicolumn{2}{|c|}{$\begin{array}{c}\text { Unstandardized } \\
\text { Coefficients }\end{array}$} & $\begin{array}{c}\text { Standardized } \\
\text { Coefficients }\end{array}$ \\
\cline { 2 - 5 } & \multicolumn{1}{c|}{ B } & Std. Error & \multicolumn{1}{c|}{ Beta } \\
\hline 1 (Constant) & 2,110 &, 665 & \\
CAR &, 020 &, 027 &, 078 \\
BOPO &,- 030 &, 006 &,- 541 \\
NPL &,- 193 &, 062 &,- 302 \\
NIM &, 439 &, 069 &, 669 \\
\hline
\end{tabular}

a. Dependent Variable: ROA

Sumber : Data Sekunder diolah menggukan SPSS versi 22, 2016 
Berdasarkan tabel 4.4 dapat dirumuskan persamaan regresi berganda sebagai berikut :

$\mathrm{ROA}=2,110+0,20$ CAR - 0,30 BOPO - 0,193 NPL +0,439 NIM berikut:

Dari persamaan analisis regresi berganda diatas maka dapat dijelaskan sebagai

1. Nilai konstan dari regresi berganda adalah 2,110 yang menunjukan bahwa nilai dari CAR, BOPO, NPL, NIM diabaikan atau sama dengan nol $\left(\mathrm{X}_{1}=\mathrm{X}_{2}=\mathrm{X}_{3}=\mathrm{X}_{4}=0\right)$ ketika nilai ROA adalah 2,110

2. Capital Adequacy Ratio memiliki nilai positif unstaderdized coefficient beta sebesar 0,20. Nilai positif dari unstaderdized coefficient beta mengindikasikan bahwa CAR memiliki pengaruh positif terhadap ROA. Dari hasil tersebut berarti setiap 1\% kenaikan dari CAR akan menambah sebesar 0,20 nilai dari ROA.

3. Beban Operasional Pendapatan Operasional memiliki nilai negatif unstaderdized coefficient beta sebesar 0,30. Nilai negatif dari unstaderdized coefficient beta mengindikasikan bahwa BOPO memiliki pengaruh negatif terhadap ROA. Dari hasil tersebut berarti setiap 1\% kenaikan BOPO akan mengurangi sebesar 0,30 nilai dari ROA.

4. Non Performing Loan memiliki nilai negatif unstaderdized coefficient beta sebesar 0,193 . Nilai negatif dari unstaderdized coefficient beta mengindikasikan bahwa NPL memiliki pengaruh negatif terhadap ROA. Dari hasil tersebut berarti setiap 1\% dari kenaikan NPL akan mengurangi sebesar 0,193 nilai dari ROA.

5. Net Interest Margin memiliki nilai positif unstaderdized coefficient beta sebesar 0,439 . Nilai positif dari unstaderdized coefficient beta mengindikasikan bahwa NIM memiliki pengaruh positif tehadap ROA. Dari hasil tersebut berarti setiap 1\% dari kenaikan NIM akan menambah sebesar 0,439 nilai ROA

Unstandardized coefficient beta digunakan karena data yang diuji adalah berskala rasio murni, dan memiliki nilai nol mutlak. Selain itu Unstandardized coefficient beta digunakan karena satuan pengukuran sama, yaitu satuan persen.

\section{Uji Siginfikan Parameter Individual (Uji Statistik t)}

Uji T-test digunakan untuk mengetahui tiap-tiap dari variabel mana saja yang memiliki pengaruh signifikan terhadap ROA. Secara parsial pengaruh dari empat variabel independen tersebut terhadap ROA ditunjukkan pada tabel 4. sebagai berikut:

\section{Tabel 4. Uji Statistik t}

Coefficients $^{\mathrm{a}}$

\begin{tabular}{|c|c|c|c|}
\hline Model & & $\mathrm{T}$ & Sig. \\
\hline 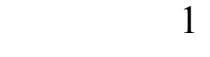 & (Constant) & 3175 & 003 \\
\hline & CAR & 0,759 & 452 \\
\hline & BOPO & $-5,345$ &, 000 \\
\hline & NPL & $-3,114$ & ,003 \\
\hline & NIM & 6,393 &, 000 \\
\hline
\end{tabular}

a. Dependent Variabel: ROA

Sumber : Data Sekunder diolah menggukan SPSS versi 22, 2016 
Hasil pengujian parameter individual diatas dapat dilihat variabel mana yang signifikan dengan melihat kolom Sig. jika nilai tersebut tidak melebihi dari angka 5\% maka variabel bebas yang uji memiliki pengaruh signifikan terhadap variabel terikat maka dapat dijelaskan sebagai berikut:

1. Nilai signifikasi dari CAR adalah 0,452 dimana nilai signifikasi lebih besar dari $5 \%$. Dari hasil tersebut $\mathrm{H}_{01}$ diterima $\left(\mathrm{H}_{\mathrm{a} 1}\right.$ ditolak) dan bisa disimpulkan bahwa CAR memiliki pengaruh tetapi tidak signifikan terhadap ROA. Nilai positif dari $t$ mengindikasikan bahwa CAR memliki pengaruh positif terhadap ROA.

2. Nilai siginifikasi dari BOPO adalah 0.000 dimana signifikasi kurang dari 5\%. Dari hasil tersebut $\mathrm{Ha}_{2}$ diterima $\left(\mathrm{H}_{02}\right.$ ditolak) dan bisa disimpulkan bahwa BOPO memiliki pengaruh signifikan terhadap ROA. Nilai negatif dari t mengindikasikan bahwa BOPO memiliki pengaruh negatif terhadap ROA.

3. Nilai siginifikasi dari NPL adalah 0.003 dimana signifikasi kurang dari 5\%. Dari hasil tersebut $\mathrm{Ha}_{3}$ diterima $\left(\mathrm{H}_{03}\right.$ ditolak) dan bisa disimpulkan bahwa NPL memiliki pengaruh signifikan terhadap ROA. Nilai negatif dari t mengindikasikan bahwa NPL memiliki pengaruh negatif terhadap ROA.

4. Nilai signifikasi dari NIM adalah 0,000 dimana nilai signifikasi kurang dari 5\%. Dari hasil tersebut $\mathrm{H}_{\mathrm{a} 4}$ diterima $\left(\mathrm{H}_{04}\right.$ ditolak) dan bisa disimpulkan bahwa NIM memiliki pengaruh signifikan terhadap ROA. Nilai positif dari t mengindikasikan bahwa NIM memliki pengaruh positif terhadap ROA.

Hasil T-test tersebut, dapat dilihat bahwa Capital Adequacy Ratio tidak memilki pengaruh signifikan terhadap Return on Asset. Jadi persamaan CAR dalam regresi berganda dieliminasi sehingga persamaan baru dari regresi berganda tersebut setelah uji hipotesis adalah :

ROA $=2,110-0,30$ BOPO - 0,193 NPL +0,439 NIM

Persamaan tersebut maka dapat dikatakan nilai konstan adalah 2,110 yang menunjukan nilai BOPO, NPL, NIM adalah nol ketika ROA berada pada nilai sebesar 2,110.

\section{Uji Signifikan Simultan F (Uji Statistik F)}

Berdasarkan output SPSS nampak bahwa pengaruh secara bersama-sama empat variabel independen pada CAR, BOPO, NPL, NIM terhadap ROA seperti ditunjukkan pada tabel 4.5 sebagai berikut :

Tabel 5. Uji statistik F

\begin{tabular}{|l|r|r|r|r|r|}
\hline Model & \multicolumn{1}{|c|}{$\begin{array}{c}\text { Sum of } \\
\text { Squares }\end{array}$} & df & \multicolumn{1}{c|}{$\begin{array}{c}\text { Mean } \\
\text { Square }\end{array}$} & F & Sig. \\
\hline 1 Regression & 11,090 & 4 & 2,773 & 18,144 &, $000^{\mathrm{b}}$ \\
& 6,112 & 40 &, 153 & & \\
Residual & 17,203 & 44 & & & \\
\hline
\end{tabular}

a. Dependent Variabel: ROA

b. Predictors: (Constant), NIM, BOPO, NPL, CAR

Sumber : Data Sekunder diolah menggukan SPSS versi 22, 2016 
Hasil perhitungan diperoleh nilai $\mathrm{F}$ sebesar 18,144 dan nilai signifikansi sebesar 0,000. Karena nilai signifikansi lebih kecil dari tingkat kepercayaan yang digunakan $5 \%$, dari hasil tersebut maka $\mathrm{H}_{\mathrm{a} 5}$ diterima $\left(\mathrm{H}_{05}\right.$ ditolak) yang berarti terdapat pengaruh yang signifikan dari variabel CAR, BOPO, NPL, NIM secara simultan terhadap ROA 2010-2014 dan dapat disimpulkan bahwa model layak untuk diteliti.

\section{Koefisien Determinasi $\left(\mathbf{R}^{2}\right)$}

Koefisien determinasi merupakan kemampuan prediksi dari keempat variabel independen (CAR, BOPO, NPL, NIM) terhadap variabel dependen ROA (Profitabiltas). Hasil dari pengujian ini menunjukan seberapa besar presentase yang menjelaskan pengaruh variabel independen terhadap variabel dependen dengan melihat Adjusted $R^{2}$ sebaga fator pengaruhnya (1-Adjusted $\left.R^{2}\right)$

Tabel 6. Adjusted $\mathbf{R}^{2}$

Model Summary ${ }^{\mathrm{b}}$

\begin{tabular}{|l|r|r|r|c|}
\hline Model & $\mathrm{R}$ & \multicolumn{1}{|c|}{ R Square } & Adjusted R Square & $\begin{array}{c}\text { Std. Error of the } \\
\text { Estimate }\end{array}$ \\
\hline 1 &, $803^{\mathrm{a}}$ &, 645 &, 609 & $0,39091 \%$ \\
\hline
\end{tabular}

a. Predictors: (Constant), NIM, BOPO, NPL, CAR

b. Dependent Variabel: ROA

\section{Sumber : Data Sekunder diolah menggukan SPSS versi 22}

Pada tabel 6, nilai koefisien determinasi (Adjusted $\mathrm{R}^{2}$ ) sebesar 0,609 atau 60,9\% hal ini berarti 60,9\% perubahan Profitabilitas (ROA) yang bisa dijelaskan oleh dari keempat variabel bebas yaitu: CAR, BOPO, NPL, NIM sedangkan sisanya sebesar 39,1\% dijelaskan oleh sebab-sebab lain diluar model. Pengaruh keempat variabel cukup besar terhadap perubahan laba dengan range tahun penelitian yang hanya 5 tahun laporan keuangan dikatakan cukup baik untuk dijadikan sebagai bahan penelitian. Selain itu rasio keuangan yang digunakan sebagai variabel independen juga dapat menjadi penyebabnya.

\section{Diskusi}

Dari hasil hitung statisktik regresi berganda diatas untuk menganalisa pengaruh dari variabel independen terhadap variabel dependen. Hasil tersebut dapat diinterpretasikan dengan melihat nilai dari nilai unstanderdized coefficient beta dari hasil regresi berganda sebagai berikut:

\section{Pengaruh CAR terhadap ROA}

Pengujian $\left(\mathrm{H}_{\mathrm{a} 1}\right)$ membuktikan variabel CAR memiliki pengaruh tetapi tidak signifikan terhadap ROA yang ditunjukkan dengan besarnya hasil uji T-tes dengan nilai t sebesar 0,078 dan tingkat signifikansi yang lebih besar dari 0,05 yaitu 0,452 . Hal tersebut tidak sesuai dengan hipotesis yang menyebutkan CAR berpengaruh signifikan terhadap ROA, sehingga hipotesis 1 menyatakan CAR memiliki pengaruh positif tidak signifikan terhadap ROA. Hasil dari uji parsial ini tidak sejalan dengan hasil dari Dendawijaya (2009) dan Kuncoro (2011) 
yang menyatakan bahwa semakin besar dan tingginya tingkat rasio dari CAR akan mempengaruhi tingkat besar dan tingginya keuntungan dari sebuah bank. Hal ini bertentangan dengan peneilitian sebelumnya yang dilakukan oleh Wahyudi (2014) yang mendapatkan hasil bahwa CAR berpengaruh signifikan terhadap ROA akan tetapi hal ini sejalan dengan penelitian lain yang diteliti oleh Hutagalung (2013) bahwa CAR tidak memiliki pengaruh signifikan terhadap ROA.

\section{Pengaruh BOPO terhadap ROA}

Pengujian $\left(\mathrm{H}_{\mathrm{a} 2}\right)$ membuktikan variabel BOPO berpengaruh signifikan terhadap ROA yang ditunjukkan dengan besarnya hasil uji T-tes dengan nilai t sebesar -0,541 dan tingkat signifikansi yang tidak lebih besar dari 0,05 yaitu 0,000 . Hal tersebut sesuai dengan hipotesis yang menyebutkan BOPO berpengaruh signifikan terhadap ROA, sehingga hipotesis 2 menyatakan BOPO memilki pengaruh negatif signifikan terhadap ROA. Hasil dari perhitungan uji parsial BOPO yang signifikan didukung dengan teori dari Ambo (2013) yang menyebutkan bahwa jika BOPO semakin kecil, maka dapat disimpulkan bahwa kinerja keuangan perbankan semakin meningkat atau membaik. Hal ini sejalan dengan penelitian sebelumnya yang dilakukan oleh Widiastuti (2014) bahwa BOPO memilki pengaruh negatif signifikan terhadap ROA.

\section{Pengaruh NPL terhadap ROA}

Pengujian $\left(\mathrm{H}_{\mathrm{a} 3}\right)$ membuktikan variabel NPL berpengaruh signifikan terhadap ROA yang ditunjukkan dengan besarnya hasil uji T-tes dengan nilai t sebesar -0,302 dan tingkat signifikansi yang tidak lebih besar dari 0,05 yaitu 0,003 . Hal tersebut sesuai dengan hipotesis yang menyebutkan NPL berpengaruh signifikan terhadap ROA, sehingga hipotesis 3 menyatakan NPL memiliki pengaruh negatif signifikan terhadap ROA. Hasil ini sejalan dengan teori dari Sutojo (2008) yaitu sebuah bank yang dirongrong oleh kredit bermasalah dalam jumlah besar akan cenderung menurunkan profitabilitasnya. Dari penelitian sebelumnya yang dilakukan oleh Mitasari (2014) juga menyebutkan bahwa NPL berpangaruh signifikan terhadap ROA, hal ini juga di dukung oleh penelitian yang dilakukan oleh Randy (2014) yang juga menyatakan bahwa NPL juga memilki pengaruh yang signifikan terhadap ROA.

\section{Pengaruh NIM terhadap ROA}

Pengujian $\left(\mathrm{H}_{\mathrm{a} 4}\right)$ membuktikan variabel NIM berpengaruh signifikan terhadap ROA yang ditunjukkan dengan besarnya hasil uji T-tes dengan nilai t sebesar 0,669 dan tingkat signifikansi yang tidak lebih besar dari 0,05 yaitu 0,000 . Hal tersebut sesuai dengan hipotesis yang menyebutkan NIM berpengaruh signifikan terhadap ROA, sehingga hipotesis 4 menyatakan NIM memiliki pengaruh positif signifikan terhadap ROA diterima. Hasil dari uji parsial NIM sejalan dengan teori dari Mahardian (2008) NIM digunakan untuk mengukur kemampuan manajemen bank dalam menghasilkan pendapatan dari bunga dengan melihat kinerja bank dalam menyalurkan kredit, mengingat pendapatan operasional bank sangat tergantung dari selisih bunga dari kredit yang disalurkan dan teori dari Pandia (2012) yang menyebutkan Rasio Net Interest Margin (NIM) merupakan rasio yang digunakan untuk mengukur kemampuan manajemen bank dalam mengelola aktiva produktifnya untuk menghasilkan pendapatan bunga bersih. Dari penelitian yang dilakukan Tan Sau Eng (2013), Sulindawati dkk (2015) juga menyatakan bahwa NIM memilki pengaruh signifikan terhadap ROA sehingga mendukung hasil dari penelitian yang dilakukan. 


\section{Pengaruh secara simultan CAR, BOPO, NPL,NIM terhadap ROA}

Pengujian F-tes diperoleh nilai $\mathrm{F}$ sebesar 18,44 dan nilai signifikasi sebesar 0,000 yang tidak lebih besar dari 5\%. Dari hasil tersebut maka $\mathrm{H}_{25}$ diterima $\left(\mathrm{H}_{05}\right.$ ditolak) yang berarti terdapat pengaruh yang signifikan dari variabel CAR, BOPO, NPL, NIM secara simultan terhadap ROA. Hal tersebut sesuai dengan hipotesis yang menyebutkan bahwa CAR, BOPO, NPL, NIM secara simultan terhadap ROA memiliki pengaruh signifikan diterima. Hasil dari penelitian ini sejalan dengan penelitian yang dilakukan oleh Hutagalung (2013) dan Mitasari (2014) juga menyatakan bahwa secara simultan CAR, BOPO, NPL, NIM memiliki pengaruh signifikan terhadap ROA sehingga mendukung hasil dari penelitian ini. Sementara dari hasil perhitungan koefisien determinasi $\mathrm{R}^{2}$ didapatkan hasil Adjusted $\mathrm{R}^{2}$ sebesar 0,609 atau 60,9\%. Dari hasil tersebut maka dapat dikatakan bahwa pengaruh dari variable CAR, BOPO, NPL dan NIM memiliki pengaruh sebesar $60,9 \%$ terhadap ROA yang berarti $39,1 \%$ di pengaruhi oleh faktor lain di luar variable yang ditelilti.

\section{Kesimpulan}

1. Pengaruh CAR terhadap ROA melalui uji-T, CAR dengan nilai thitung sebesar 0,759 dan taraf signifikasi sebesar 0,452 lebih besar dari 0,05 tersebut maka CAR bengaruh positif tetapi tidak signifikan terhadap ROA. Pengujian ini secara statistik membuktikan bahwa CAR memiliki positif pengaruh tetapi tidak signifikan terhadap ROA. Artinya kecukupan modal tidak memiliki pengaruh positif signifikan terhadap profitabilitas sebuah bank.

2. Pengaruh BOPO terhadap profitabilitas yang dukur dengan ROA melalui uji-T, BOPO dengan nilai t hitung sebesar $-5,345$ dan taraf signifikasi sebesar 0,000 lebih kecil dari 0,05 tersebut maka BOPO memiliki pengaruh negatif signifikan terhadap ROA. Pengujian ini secara statistik membuktikan bahwa BOPO memiliki pengaruh signifikan terhadap ROA. Artinya efisiensi memiliki pengaruh signifikan terhadap profitabilitas sebuah bank.

3. Pengaruh NPL terhadap profitabilitas yang dukur dengan ROA melalui uji-T, NPL dengan nilai t hitung sebesar -3,114 dan taraf signifikasi sebesar 0,003 lebih kecil dari 0,05 tersebut maka NPL memiliki pengaruh negatif signifikan terhadap ROA. Pengujian ini secara statistik membuktikan bahwa NPL memiliki pengaruh negatif signifikan terhadap ROA. Artinya resiko kredit bermasalah memiliki pengaruh negatif signifikan terhadap profitabilitas sebuah bank.

4. Pengaruh NIM terhadap profitabilitas yang dukur dengan ROA melalui uji-T dengan nilai t hitung sebesar 6,393 dan taraf signifikasi sebesar 0,000 lebih kecil dari 0,05 tersebut maka NIM memiliki pengaruh signifikan terhadap ROA. Pengujian ini secara statistik membuktikan bahwa NIM memiliki pengaruh positif signifikan terhadap ROA. Artinya pendapatan dari bunga bersih memiliki pengaruh positif signifikan terhadap profitabilitas sebuah bank.

5. Pengaruh variabel independen $\mathrm{CAR}, \mathrm{BOPO}, \mathrm{NPL}$, NIM secara simultan terhadap profitabilitas yang diukur dengan ROA melalui uji-F dengan nilai $\mathrm{F}$ hitung sebesar 18,144 dan taraf signifikasi sebesar 0,000 lebih kecil dari 0,05 tersebut maka CAR, BOPO, NPL, NIM yang secara simultan memiliki pengaruh signifikan terhadap ROA. 
Nilai dari Adjusted $R^{2}$ menunjukan besarnya pengaruh dari variable independen terhadap variable dependen adalah $60,9 \%$ yang sisanya $39,1 \%$ dipengaruhi faktor eksternal diluar dari variablel yang diteliti. Dapat disimpulkan pengaruh dari kecukupan modal, efisiensi, kredit bermasalah, dan pendapatan bunga bersih secara bersamaan memiliki pengaruh signifikan terhadap profitabilitas sebuah bank. 


\section{Daftar Pustaka}

Agus Salim (2006). Teori \& Paradigma Penelitian Sosial. Yogyakarta: Tiara Wacana.

Aldridge, John.E Siswanto Sutojo. (2008). Good Corporate Governance. Jakarta: PT.Damar Mulia Pustaka.

Arikunto, S. (2010). Prosedur penelitian Suatu Pendekatan Praktik. (Edisi Revisi). Jakarta: Rineka Cipta.

Arthesa, Ade dan Edian Handiman. (2006). Bank \& Lembaga Keuangan Bukan Bank. Jakarta: Indeks.

Dahlan, Siamat. (2008). Manajemen Lembaga Keuangan, Edisi Keempat. Lembaga Penerbit FE Universitas Indonesia, Jakarta.

Fahmi, Irham. (2012). Analisis Laporan Keuangan. Cetakan Ke-2. Bandung: Alfabeta.

Frianto, Pandia, (2012). Manajemen Dana dan Kesehatan Bank. Jakarta: Rineka Cipta.

Ghozali, Imam. (2011). Aplikasi Analisis Multivariate Dengan Program SPSS. Edisi Ke-5. Semarang: BP Universitas Diponogoro.

Harahap, Sofian Safitri. (2010). Analisis Kritis Atas Laporan Keuangan. Jakarta: Rajawali Persada.

Istijanto, (2009). Aplikasi Praktis Riset Pemasaran. Jakarta: Gramedia Pustaka Utama.

Kasmir, (2012). Analisis Laporan Keuangan. Edisi Keenam. Jakarta: PT. Raja Grafindo.

Kuncoro, Mudrajad., Suharjono. (2011). Manajemen Perbankan Teori dan Aplikasi. Edisi Kedua. Yogyakarta: BPFE

Lukman, Dendawijaya. (2009). Manajemen Perbankan.Edisi Kedua. Jakarta: Ghalia Indonesia.

Mudrajad, Kuncoro dan Suhardjono. (2011). Manajemen Perbankan Teori dan Aplikasi. Yogyakarta: BPFE Yogyakarta.

Munawir. (2010). Analisis laporan Keuangan. Edisi 4. Yogyakarta: Liberty.

Nazir, Mohamad. (2013). Metode Penelitian. Jakarta: Balai Aksara.

Riyadi Selamet, (2006). Banking asset and liability management. Jakarta: Fakultas Ekonomi Universitas Indonesia.

Sugiyono. (2012). Metodologi Penelitian Kuantitatif Kualitatif dan $R \& D$. Bandung: Alfabetha. 
Sutrisno, Edi. (2009). Manajemen Sumber Daya Manusia Edisi Pertama. Jakarta: Kencana Prenada Media Group.

Taswan. (2010). Manajemen Perbankan Konsep, Teknik, dan Aplikasi. Edisi Kedua. Yogyakarta: UPP STIM YKPN

Ambo, Aman. (2013). Analisis Kinerja Keuangan Dengan Menggunakan Metode Camel Pada Bank Umum Swasta Nasional Devisa Di Indonesia Tahun 2007-2011, SKRIPSI. NHAS Makasar.

Billy Arma Pratama. (2010). Analisis Faktor-Faktor Yang Mempengaruhi Kebijakan Penyaluran Kredit Perbankan ( Studi Pada Bank Umum di Indonesia Periode tahun 2005-2009). Semarang: Universitas Dipenogoro, 397-403. ISSN 1907-9958.

Nusantara, Ahmad Buyung. (2009). Analisis Pengaruh NPL, CAR, LDR, DAN BOPO Terhadap Profitabilitas Bank (Perbandingan Bank Umum Go Publik dan Bank Umum Non Go Publik di Indonesia Periode Tahun 2005-2007. Tesis Program e-Journal Ak. Universitas Pendidikan Ganesha Jurusan Akuntansi (Volume 2 No.1 Tahun 2014) Studi Magister Manajemen. Universitas Diponegoro.

Puspitasari, Diana. (2009). Analisi pengaruh CAR, NPL, PDN, NIM, BOPO, LDR, Dan Suku Bunga Sbi Terhadap ROA. Tesis. Magister Manajemen, Universitas Diponegoro Semarang.

Talattov, Abra Puspa Ghani. dan FX Sugiyanto. (2011). Analisis Struktur, Perilaku dan Kinerja Industri Perbankan di Indonesia Tahun 2003-2008. Semarang. Universitas Diponegoro.

Booklet Perbankan Indonesia Edisi Maret 2014, Bank Indonesia

Peraturan BI No 14/26/PBI/2012 tentang Kegiatan Usaha dan Jaringan Kantor Berdasarkan Modal Inti Bank.

Peraturan BI No 15/2/PBI/2013 tentang Penetapan Status dan Tindak Lanjut Pengawasan Bank Umum Konvensional.

PSAK No. 31 Akuntansi Perbankan.

SE BI No 13/13/DPNP tanggal 16 Desember 2011 perihal Perubahan Ketiga atas Surat Edaran Bank Indonesia Nomor 3/30/DPNP tanggal 14 Desember 2001 perihal Laporan Keuangan Publikasi Triwulanan dan Bulanan Bank Umum serta Laporan Tertentu yang Disampaikan kepada Bank Indonesia.

SE BI No 13/30/DPNP tanggal 16 Desember 2011 perihal Laporan Keuangan Publikasi Triwulanan dan Bulanan Bank Umum serta Laporan Tertentu yang Disampaikan kepada Bank Indonesia.

SE BI No 15/11/DPNP tanggal 8 April 2013 perihal Fasilitas Pendanaan Jangka Pendek Bagi Bank Umum. 
SE BI No.6/23/DPNP tanggal 31 Mei 2004 perihal Sistem Penilaian Tingkat Kesehatan Bank umum dan lampiran.

UU Republik Indonesia nomor 10 tahun 1998 tentang Perbankan. 